
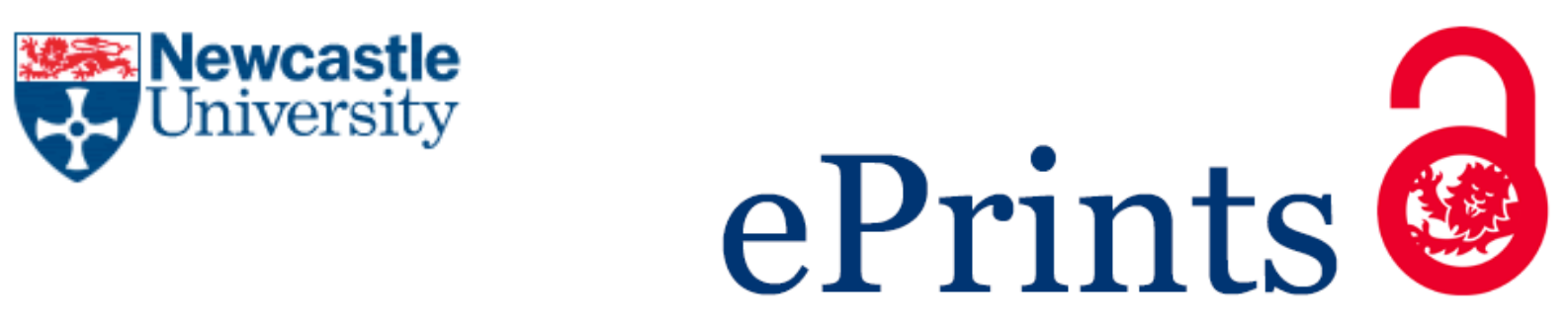

Mavin S, Williams J, Bryans P, Patterson N. 'Woman as Project': Key issues for Women Who Want to Get On. In: Broadbridge AM; Fielden SL, ed. Handbook of gendered careers in management: Getting in, getting on, getting out. Cheltenham: Edward Elgar, 2015, pp.305-321.

\title{
Copyright:
}

This is a draft chapter / article. The final version is available in Handbook of gendered careers in management: Getting in, getting on, getting out edited by Broadbridge AM; Fielden SL, published in 2015, Edward Elgar Publishing Ltd http://dx.doi.org/10.4337/9781782547709

The material cannot be used for any other purpose without further permission of the publisher, and is for private use only.

DOI link to article:

https://doi.org/10.4337/9781782547709.00028

Date deposited:

$13 / 09 / 2017$

Embargo release date:

02 July 2015 


\section{'Woman as a Project': Key Issues for Women Who Want to Get On}

\section{S. Mavin*, J. Williams, P. Bryans and N. Patterson}

\section{Northumbria University UK}

Earlier version of chapter forthcoming in

The Handbook of Gendered Careers in Management: Getting In, Getting On, Getting Out (eds.) A. Broadbridge and S. Fielden, Edward Elgar Publishers.

\section{Introduction}

The following chapter explores senior women's key issues for women who want to get on as managers and leaders. We present analysis drawn from a wider qualitative study of 81 senior women who hold UK FTSE 100/250 Executive/Non-Executive Director and/or influential leader positions ${ }^{1}$, set against a background assumption that "male-defined constructions of work and career success continue to dominate organizational research and practice" (O’Neill et al, 2008: 727). The senior women participants have achieved a traditionally "masculine strategic situation" (Tyler, 2005: 569) in breaking through the gendered glass ceiling (Morrison et al., 1992) and in doing so may be viewed as no longer "the organizational second sex" or "Others of management" (Tyler, 2005: 572). The study, following Ellemers et al. (2012) and Chesterman et al. (2005), therefore explores experiences of women in high places who have overcome gendered barriers to achieve senior leader positions, and advances Terjesen et al.'s (2009: 332) call for “truly innovative research into the female directors' experiences" currently lacking in the literature.

\footnotetext{
${ }^{1}$ The Senior Women at Work Project was supported by Northumbria University 2012-2013

*corresponding author Sharon.mavin@northumbria.ac.uk
} 
Our analysis, subsequent themes and conceptualization result from 81 senior women's responses to the interview question; what are the key issues women need to be aware of as they progress into senior positions? The women participants are not a homogeneous group and while they share experiences as 'elite' women in organizations and at the same time we recognize women as oppressed and marginalized as leaders in patriarchal organizations, they do not share the same experiences (Bryans and Mavin, 2003; Griffin, 1995).

We are aware that our analysis of key issues for women who want to get on is influenced by the participant's biographies, career histories, bio-data, life stages and their societal and organisational contexts. Our assumptions that “women's careers are complex and multi-dimensional, yet work practices appear to exist in a single dimension - the male defined organizational dimension" (O’Neill et al, 2008: 735) and that after decades of women working, the predominant attitude is still 'think manager, think male' (Schein, 1991; 2007), provide a gendered background to, but are not the focus of our research. We offer six themes which encapsulate senior women's key issues for women who want to get on as managers and leaders and draw upon doing gender well and differently against sex-category (Mavin and Grandy, 2011, 2012) to conceptualize our contribution of 'woman as a project'; an architecture for instrumental personal organizing of holistic [personal and career] lives.

\section{Understandings of gender}

Gender is a social construction, a socially produced binary division and distinctions between women and men, and masculinities and femininities (Acker, 1992). This position reflects recent developments in gender studies which have moved the debate from essentialized concepts which located masculine behaviours or traits associated with men and feminine 
behaviours or traits associated with women as a consequence of biology. Gender can now be understood as an achievement; we do gender through ongoing negotiations, 'doing gender' through a "complex of socially guided perceptual and interactional and micropolitical activities that cast particular pursuits as expressions of masculine and feminine 'natures"' (West and Zimmerman, 1987: 126). Constructing this argument, West and Zimmerman (1987) distinguish between sex, sex categorization and gender. This is a feminist tactic of separating physiological differences [sex] and social behaviours [gender] to unpack gender and open up the binary to scrutiny and disruption. However there remains some debate over the connections between sex and gender, as it is suggested that when doing gender, people are already categorized by sex, as the body cannot be said to be neutral (Kelan, 2010). The fruitfulness of the gender binary continues to occupy gender researchers, as the potential to destabilize the binary has implications for the values, behaviours and meanings available to, and acceptable for, both women and men (Mavin and Grandy, 2011, 2012). Rather than undoing gender (Butler, 1990, 2004), it is suggested that gender undergoes processes of being re-done or done differently (Mavin and Grandy, 2011) as women move into spaces and ways of organizing previously considered a male/masculine enclave and also when they perform masculinities.

This chapter is based upon this position; that gender can be done well and differently against sex-category through simultaneous, multiple enactments of femininity and masculinity (Mavin and Grandy, 2011, 2012). Women can do gender well if they do so in congruence with the female sex category whilst simultaneously doing gender differently by engaging in behaviours associated with masculinity (Mavin and Grandy, 2011). We continue to incorporate sex category into doing gender, as we recognize that gender is done from a body which is not neutral, but already positioned via sex category (Kelan, 2010). This position recognizes that the gender binary, femininities and masculinities and management 
can begin to become decoupled (Billing, 2011) as women reduce negative backlash when they manoeuvre between the behaviours expected of women and those expected of men in becoming leaders (O’Neill and O'Reilly, 2011). This process of doing gender well and differently is dynamic, however we recognize that through ongoing gender stereotyping in society and organizations, women and men continue to evaluate themselves and are evaluated by others against the femininity-masculinity binary divide (Mavin and Grandy, 2011, 2012).

\section{The context for UK senior women}

The UK context in terms of seniority remains largely male. The recent Female FTSE report by Cranfield University (2013) which outlines the numbers and location of women in top UK companies, highlights that only $17.3 \%$ of women hold directorships in the FTSE 100 and as low as $13.3 \%$ in the FTSE 250 . In real terms FTSE 100 women hold only 18 Executive Directorships versus 292 men and the FTSE 250 has only 32 women with Executive Directorships versus 558 men. Of the FTSE 100 appointments in the past 6 months, 74\% have been to men. The Sex and Power Report, Who Runs Britain (2013) outlines how Britain is ranked only $60^{\text {th }}$ out of 190 states for the number of women legislators and in a population of $51 \%$ women, only $36.4 \%$ of public appointments are women: $22.5 \%$ of women are Members of Parliament; $14.2 \%$ are university Vice Chancellors and $15.6 \%$ are High Court Judges. This picture presents the societal context for women and the saliency of ongoing research into women's experiences of management and leadership and in particular, individual senior women's experiences. 
These stark figures reflect organizational contexts and structures which we contend remain gendered in ways which detrimentally shape women's experiences (Connell, 1987; Gherardi 1994) as they move towards, and take up management and leadership positions. Understanding the perpetuation of gendered organizing contexts requires an appreciation of the role of patriarchy and hegemonic masculinity. Patriarchy as socio-structural practices (Walby, 1989) provides the backcloth to gendered relations as it operates at macro [societal], meso [organizational] and micro [everyday interactions] levels (Billing, 2011; Connell, 1987), expressed through hegemonic masculinity which maintains assumptions of masculine superiority (Knights and Kerfoot, 2004) and perpetuates the association of men/masculinities with management and leadership (Connell, 1987; Gherardi, 1994). Women who want to get on experience a double bind whereby they are expected to perform femininities associated with being a 'woman' whilst also demonstrating behaviours expected of manager/leaders [associated with masculinity] (Gherardi, 1994). In order to manoeuvre between these expectations and the gendered contexts they construct, senior women may opt to perform femininities and masculinities simultaneously and so do gender well and differently (Mavin and Grandy, 2012, 2013). Yet, women may also engage in, or ventriloquize patriarchal attitudes (Brown, 1998). Engaging with patriarchy has consequences for the behaviours and relationships women can develop and sustain, and limits the femininities deemed to be appropriate for women to gendered stereotypes (e.g. caring, empathic, compliant), which Connell (1987) suggests can be called emphasized femininities. Women may challenge hegemonic masculinities construction of 'accepted' femininities by doing gender well [e.g. engaging in such stereotypical femininities] and simultaneously doing gender differently [e.g. by engaging in competition and ambition] (Mavin and Grandy, 2012; 2013). 
An embedded resistor to women's doing of gender well and differently is the masculine form of management associated with senior positions, argued to be "imbued with conceptions of rationality and instrumental control, taken for granted and which render gender largely unproblematic" (Ross-Smith and Kornberger, 2004: 296). Such masculine rationality is centred on control; "an extreme version of competitive masculinity" (RossSmith and Chesterman, 2009: 6) where senior leadership is understood as a "masculine strategic situation" (Tyler, 2005: 569) which shapes senior positions through embedded patriarchy and hegemonic masculinity reproducing masculine discourses and practices (RossSmith and Chesterman, 2009). Such contexts offer interesting and potentially informing sites through which senior women's experiences can be explored. Further, while women are now associating themselves with management and leadership (Billing, 2011), women may still need to manage negative responses if they jolt other organizational members' gendered expectations (Mavin, 2009), in particular those who do not associate management and leadership with women. We recognize that women may not have awareness of the extent to which these gendered contexts shape experiences, therefore these debates ground our research question: what are the key issues women need to be aware of as they progress into senior positions?

\section{Research approach}

This chapter draws upon data derived from semi-structured interviews with 81 senior women working in UK based organizations: 36 women directors/non-exec directors in UK FTSE 100/250 companies and 45 influential women working in a UK region. Participant ages range from 33-67 years. 73 women self-declared as white British/Irish/Other white backgrounds; 2 as black/mixed backgrounds, with 6 non-declared. 62 women worked full time, 14 part-time, 
with 5 non-declared. Face to face (56) and telephone (25) interviews took place, averaging approximately one and a half hours. Interviews were recorded and transcribed by a professional transcribing service. We did not ask senior women what they perceived as career success or career barriers rather we explored women's reflections on their journeys to date. A flexible interview guide was used which began with life/career history, asked participants about their experiences of being a woman moving into senior positions and progressed to areas of friendship, competition, cooperation and ambition. Questions prompting reflections and learning were also included at the end of the interview.

Building upon Elliott and Stead (2008: 168) "in order to get to the heart of women leaders' experiences" we focus here upon analysis of data which emerged in response to the question 'what are the key issues women need to be aware of as they progress into senior positions?,' answered by all 81 participants. Analysis of these responses and cross-transcript analysis was highly iterative, moving between "phases of coding, literature review, and conceptualization of the data" (Ladge et al., 2012: 1456). While the first author completed the initial coding inductively by creating thematic categories, through discussion, all authors agreed on the final themes presented here. We now discuss each of the emergent themes to explore the key issues for women who want to get on as managers and leaders.

\section{Senior women's key issues for women who want to get on}

We are conscious reflexively of the interview questions being grounded in aspects of gender and of the research specifically publicised as focussing upon senior women's relationships with other women at work. Therefore the interviews provided a unique opportunity to ask 
senior women what they viewed as the key issues for women who want to progress to senior positions. We recognize that the senior women and researchers were co-constructing learning from the participant's career journeys and experiences to date during the interview as a site for reflective learning. The following six themes emerged from analysis of senior women's accounts and provide a broad overview of the key issues identified.

To be or not to be a woman ...

This theme reflects the senior women's positioning of themselves as women leaders or as leaders and therefore gender neutral against the gender binary. Those who positioned themselves as leaders-gender neutral did not want being a woman to be relevant to their positions and were clear that it was business that counted; there was almost nothing that was a problem unique to women and if individuals wanted to achieve, they could do so regardless of gender. This gender neutral positioning was reflected in comments that women should not ask for nor expect special treatment or to be treated any differently to men. Senior women recommend that women do not use their femininity, their appearance or being a woman as an excuse; thus eliminating gender and constraining women's opportunities to do gender well.

Those women who positioned themselves as women leaders felt that women should stop worrying about being women, value themselves as women and stop apologising for being a woman. They did not want women to become men, to adopt male traits or to become one of the boys. There was an overall awareness from the participants of the gendered nature of organization and of the discrimination women still face and advice was for women to be realistic about the possibility of being the only woman in the room as they rise hierarchically; by doing your homework, picking the right company [women-readiness] and being aware of 
having to confront masculine heroic leader expectations. Their advice was to be aware of assuming and deploying authority while at the same time, not to be too aggressive and testosterone driven and "scare the horses" which could limit the appointment of other women. Thus women are able to do gender differently but not too differently against the binary that they render themselves and other women vulnerable.

Senior women make comparisons to men in identifying their key issues for women who want to get on. They recommend that women reflect on the way men go for the "quick wins" [influencing key people] when they get promotion and have already got a plan for "everybody to say how brilliant they are", whereas women get "too stuck into the job" rather than the relationships around them. Senior women repeatedly point out that women must work harder than men, be on top of their game and not make mistakes, which are less tolerated than when men make them. Again senior women recommend women lose or tone down their femininity in the leader role, in that women should ensure their focus is not on their clothes and children [femininity] but on their competence [masculinity] when appearing in the press/media because this is the case for men.

Family matters

Further contradictions surface in the theme of 'family matters' where dependent upon the women's positioning of themselves against the gender binary, family matters should not be a barrier to women who want to get on, or family matters should not be an issue for an organization i.e. women should not expect special treatment, even though in general they recognized that the weight of family responsibilities falls to women. This was also influenced 
by the senior women's age and life-stage in that younger senior women were more adamant that the organization had a responsibility to support women in successfully managing family matters and a senior career. However women at later life-stages did recommend that women should not be afraid of having a family, a personal life and a career and to remember "you cannot go home and cuddle a career." Regardless, senior women agree that women should plan and organize their family matters in ways which work with their overall life and career ambitions, including choosing the right partner carefully. Numerous senior women who had children told us of how their partners work at home, work part time or have retired to take the lead in family responsibilities, so that personal relationships were grounded in equality. This type of life planning requires early self-awareness and decision making for women and an integration of personal life choices and career.

Again senior women compared themselves to men in terms of family matters where it was perceived that men in organizations did not understand the impact of maternity and returning to work for women leaders. Senior women recommend that women talk more and act positively about these issues as a means of 'normalizing' women's experiences. An example of this is a senior woman discussing that she did not accept any resignations from women on maternity leave or upon return "until the hormones had reduced."

Becoming more authentic and building self-efficacy

Being 'true' to yourself, being yourself, being genuine, becoming authentic, knowing oneself, what you stand for, knowing your values and having a moral compass were highlighted as incredibly important enablers of success. This 'becoming more authentic' was 
discussed in terms of how women should: work hard on knowing who they really are; reflect on management and leadership styles and on the way they develop relationships. Integrated with becoming more authentic is advice for women to develop and demonstrate self-efficacy as a leader; believing in one's capabilities to organize and take action to succeed (Bandura, 1977). There were numerous comparisons between men and women's levels of self-efficacy and self-belief in their abilities in delivering the top jobs in organizations, with women recommended to develop their self-belief, resilience and to value their abilities. This leadership self-efficacy is not grounded in a general concept of confidence or competence (Vinnicombe, 2013). These women are highly competent and knowledgeable. Rather, this self efficacy reflects women committing effort to achieving their own specific outcomes, attributing failure to things within their control and recovering quickly from set-backs (Bandura, 1977). This includes imagining / visualizing yourself in a position to reduce insecurity and build self-efficacy; ignoring any "little voices" of self-criticism or self-doubt; developing leadership self-efficacy through organizing all aspects of life to enable women to perform to the best of their abilities; developing self-belief, resilience, confidence in own abilities and valuing themselves in ways which reduce insecurity. Women are recommended to work at reducing personal over-sensitivity and investing in development techniques to manage over-worrying and anxiety, seen as debilitating, energy-sapping and a barrier to women's self-efficacy in senior roles.

Investing in your development

The theme of 'investing in your development' has a functional 'do this and that' feel but at its core the process of women committing to personal learning and development was a key issue 
which provides the scaffolding for women 'becoming more authentic and developing selfefficacy'. Senior women recommended that women who want to get on are prepared to learn, change, adapt and be flexible; are prepared to rehearse and practice 'being' a leader; are prepared to commit to coaching for job interviews; to engage in networking, join professional organisations and get onto organizational talent programmes. Spending time observing senior leaders, in terms of what to do and not to do, learning to operate in contingent ways and identifying strong role models were also key issues, as well as developing relationships with other external senior women to discuss challenges. Senior women emphasise women not being afraid to commit to coaching and mentoring early in their careers to support personal development and to develop emotional intelligence and self-awareness, critical to becoming more authentic and supporting the achievement of other key issues.

There was no doubt that long term career planning, being overt about which role is next for you; swapping careers, sectors, moving sideways; planning and making career moves along the lines of a game of chess, was a key issue for women who want to get on; utilizing agency in manoeuvring towards their life goals. Investing in their own development for the future to support career planning and thus making themselves the project, was reiterated as critical.

Outstanding credibility but not the solid Lieutenant

In demonstrating competence as a key issue for women who want to get on, senior women advised women to be on top of their game, the expert, with internal [self-belief and selfefficacy] and external [enacted/reputational] credibility, demonstrated through competence 
and delivery and high professional standards. Women who want to get on should be trusted as an expert advisor; be loyal; be seen to take responsibility; know everything there is to know about an organization's purpose whilst developing their own personal brand. Senior women had no doubt that women have to work harder than men to get on and have to make sacrifices but their counter-advice was for women to balance this exceptional credibility without working too hard, to prevent exhaustion. Women should not take on too much and underperform. Women must be able to have a vision of the wider world and with their own brand, make an impact on the organization. However again this is a balancing act for women and should be enacted without getting stuck in middle management positions or becoming too much of a specialist, in that if women focus on the specifics of the job, they risk being overlooked in terms of leadership potential. Therefore women should learn to balance their exceptional credibility without being "the solid lieutenant", developing their potential; moving from "doer to thinker creator."

Functionally senior women identified profit and loss and line management experience as critical issues for women who want to get on. Women should take a strategic role in developing excellent relationships with stakeholders and shareholders and demonstrate understanding of the bottom line; to get the profit and loss responsibility and move sideways to access it like a game of chess, [doing gender differently and seizing the masculine strategic prerogative], as well as simultaneously demonstrating how they can nurture and act corporately within the organization and have line management experience [doing gender well by meeting more feminine stereotypes].

The notion of women organizing themselves is reflected again in this theme. Senior women used a metaphor of juggling balls to reflect what was necessary in women's home and professional life. This is a common theme in women in management research, the juggling of multiple roles and family concerns, evidencing the proposal that women's career 
choices are about more than just paid work (O’Neill et al., 2008). Therefore women need to be good organizers, multi-taskers, good delegators and be able to "steal with pride" rather than re-invent the wheel to demonstrate exceptional credibility. The critical message is that women are advised to organize their work and personal lives to provide an architecture which enables their progression.

Bravery counts

The final theme of 'bravery counts' reflects the realities of putting the key issues into action and relates to organizational politics and women's personal behaviours and performance. Women in management are often reluctant to engage in and often disassociate themselves from organizational politics as distasteful, viewed as a boy's game related to the masculine strategic objective (Tyler, 2005). However in a similar way to understanding themselves and becoming more authentic, senior women advise women to invest in fully understanding the organisational context, relationships and organizational politics; to know their audiences and be instrumental in how they communicate and perform when engaging with them. Here senior women advise women to do gender differently in that political behaviour is normally the domain of men but this can also be perceived as recommending women to conform to masculine norms.

In understanding how the social organization works, women are recommended to act as the de facto leader before formal appointment. In their career planning women should work out who is influential and/or what organizations will be critical to progress, thus emphasising the instrumentality of career planning. Women are recommended to identify who is a good sponsor in order to politically align themselves, influence people and develop 
appropriate allies and to recognize the need for, and develop their own, "political and organisational savvy" if they want to get on, so that they learn the invisible rules of the game or "combat" and understand "sub-agendas" and "political currents that run beneath" the organization. Understanding organizational politics and social relations enables women to fully engage and influence and also to know where their allies and enemies are located and how to manage them.

Senior women also recommend that women who want to get on are brave and take risks and are prepared to "seize the moment" in their behaviours and actions as a manager or leader - feeling the fear and doing it anyway. Women should go for "quick wins" influencing significant others, move out of their comfort zone to gain experience and be prepared to stand alone when necessary. In practice this means speaking out, asking the "pertinent questions", asking "one good question in every meeting", therefore being assertive, confident, having an opinion and pushing yourself forward and doing gender differently. Senior women advise that women should not be afraid to challenge [and do gender differently] but they need to be prepared "for the fact that people will not like it", as masculine behaviour from women jolts gender stereotypes (Mavin, 2009), provoking back-lash responses. Senior women recommend that knowing and understanding your audiences helps mediate this backlash. In terms of challenging gendered stereotypes, senior women advise that women are prepared to "sing their own praises", "cultivate the art of gentle boasting"; being able to express ambition and competition confidently, being "very overt about the next job they want" and continually reviewing aspirations so that they can articulate these when appropriate. 'Bravery counts' reflects senior women's recognition of how risky the performance of masculinities is for individual women and the need to find a balance between behaviours needed to challenge the stereotypes and not "scaring the horses." 


\section{Discussion}

\section{Woman as a project}

Women's experiences take place within gendered contexts and structures at the macro-mesomicro level which constrain and enable women's agency. We recognize that studies into women in management at the individual micro level face the danger of falling into the 'blame the woman' trap, so that women are treated as deficit against male norms with suggested strategies at risk of being perceived as 'fixing the women' (Mavin, 2008). This is illustrated by Cheryl Sandberg's (2013) recent argument that women can have it all but they subconsciously sabotage their own careers through fear, guilt and willingness to conform to stereotypes, versus the debates which highlight that change is required at the macro level, in society (e.g., The Sex and Power Report, Who Runs Britain, 2013) and at the meso level, in organizations to change masculine cultures and adapt to the needs of women in the workplace (e.g., Maddock, 2005; Mavin, 2001; Bryans and Mavin, 2003). We recognize the need for change at each level, along with a commitment to gender politics for women managers and leaders, where women are more aware of, and better prepared to learn, 'the rules of the game' at each of the levels in order to be able to challenge, disrupt and orchestrate change through various strategies appropriate to individual women. One way forward for women who want to get on within gendered contexts is to view themselves as their own project.

The themes presented are interlinked, complex, fluid, simultaneous, at times contradictory and take place within gendered contexts against a masculine norm of management and leadership. The themes are relational, socially constructed and reflect how women do gender well and differently, simultaneously against the gender binary (Mavin and Grandy, 2011, 2012). In analysing senior women's experiences as a means of further 
understanding key issues for women who want to get on we offer a conceptualization of 'woman as a project.' Woman as a project is grounded within gendered contexts and integrates two features: conscious awareness of doing gender well and differently simultaneously and instrumental personal organizing (see Figure 1).

\section{$<$ TAKE IN FIGURE $1>$}

This conceptualization draws upon a project as a conceptual, processual plan for women's awareness, outlook, preparation and decision making, which enables women to engage in contingency planning in their life course and to prepare for actions and alternative actions. As a concept, 'woman as a project' is supported by an architecture for design, structure and behaviour in navigating women's whole life course, enabling consciousness to the gendered contexts and possibilities for women's decision making and agency within their personal and work lives. 'Woman as a project' requires a commitment to self-awareness, understanding oneself, one's values, ambitions and aspirations, across and at key points, in their lives. In approaching their lives as a project, women commit time, effort and planning, over time and space, in processes of holistic, instrumental, personal 'organizing' which requires commitment to the significant organizing of women's lives, aspirations, ambitions across their life and not just work history. In this way we respond differently to the call by Hirsh and Jackson (1990) that careers should be accommodated around the reality of women's lives, allowing them to make a meaningful investment in both occupational and family roles; proposing a holistic integration to enable women's instrumentality and agency.

'Woman as a project' provides an architecture to integrate women's lives which incorporates two significant features: conscious awareness of doing gender well and differently against sex-category, including gender aware positioning self as a woman leader 
or as a leader, and instrumental personal organizing. Through these features the project architecture integrates as interlocking processes, the key issues that senior women identified for women who want to get on as managers or leaders. 'Woman as a project' enables women to view their life course from a holistic perspective rather than one which is compartmentalized and in this way takes account of the complex and interwoven choices and constraints in women's career and life development (Powell and Mainiero, 1992) as well as acknowledging how women's career and life responsibilities ebb and flow against life stages (O’Neill and Bilimoria, 2005). This commitment to 'woman as a project' is grounded, not in developing women against a deficit model of male norm at the macro-meso-micro levels but as a guiding architecture for how a woman might approach and/or construct themselves in organizing their life's ambitions and aspirations.

A feature of the 'woman as a project' concept is a micro-level individual consciousness of doing gender well and differently against sex-category which opens up possibilities of disrupting male norm assumptions and gendered expectations. Raising awareness amongst women of their performances of doing gender well and differently simultaneously may enable alternative subjectivities to be further embedded and accepted in society and organization so that women and men are more able to demonstrate a range of subjectivities. We contend that what is unique about this study is the senior women's awareness of the continuing gender binary for managers and leaders and their advice for other women to be conscious of positioning themselves as women leaders or as leaders-gender neutral. These choices are not either/or, they can be contingent and can operate simultaneously as women 'do' manager and leader roles. Contradictions surfaced from women who position as gender neutral leaders but who expect society and organizations to be changing to adapt to women's family and caring responsibilities. We contend that it is the 
conscious awareness of these contradictions which empowers women's agency and that the 'woman as a project' architecture has the potential to enable this awareness.

Becoming more authentic with self-efficacy is a theme within the project architecture. In advancing Mainiero and Sullivan's (2005) claims that authenticity and being true to oneself will be prevalent late-career, as the theme held resonance across over half the senior women involved in the research and was evident across senior women who share similar hierarchical positions [the top of their organization] but different career stages [i.e. they are mid-through to-late career] and who also spanned the age range of the research population, becoming more authentic has risen in priority and is no longer apparent just at late-career.

Through the themes of 'family matters,' 'outstanding credibility but not solid lieutenant' and 'investing in development,' senior women emphasize that women who want to get on should instrumentally organize and plan their lives. This is not a new finding in the field of careers for women in management, where women are often thwarted in this by gendered society and organizational structures and expectations, sometimes resulting in women developing alternative career patterns against a hierarchical male norm career. However, this current research offers a 'holistic' way of viewing life course beyond career planning. Senior women tell us that rather than focussing solely on the job they are doing, women could make themselves the 'organizing project' in terms of their 'whole' life rather than just work. In not being the 'solid lieutenant' or 'stuck in middle management', the concept of "woman as a project" highlights how women could 'stop doing the doing' and stop fully committing to their current role, to step back and focus upon themselves as their life time project. Women who want to get on are encouraged to see themselves as something to be more instrumentally organized, planned, evaluated and implemented successfully. We contend that the "woman as a project" concept takes place within multiple gendered relationships and contexts, where becoming consciously gender aware of doing gender well 
and differently and instrumental personal organizing are key enablers and where an architecture integrates through instrumental organizing, chess-like career planning, development of key competences, personal and family matters, strategic life planning and engaging in learning and development.

\section{Conclusion}

We are aware that this research may be limited by the nature of the sample; senior women in UK organizations and that this could open up criticism from those who argue limiting studies of women's careers in management to samples of elite/ successful women represents only a small proportion of the population of women in management, so that generalizations may not be relevant for the majority of women (O'Neill et al., 2008). The chapter is underpinned by an assumption that the learning offered is for those women who are motivate to progress. We contend that as the 'woman as project' concept integrates women's personal and career lives, it has transferability to women at all levels and life stages in management and leadership.

To summarize the chapter, we have outlined the emergent themes resulting from our analysis of senior women's responses to the question 'what are the key issues women need to be aware of as they progress into senior positions,' and theorized six emergent themes drawing upon doing gender well and differently simultaneously against sex-category to offer a concept of 'women as a project' and its associated architecture as an enabler to supporting women who want to get on as managers and leaders in organization. 


\section{Acknowledgements}

Our thanks go to the senior women who engaged in the research and to the research assistants on the wider 'Senior Women at Work' project, Edita Petrylaite and Stephanie Haeussler, Northumbria University.

Gendered contexts at the macro-meso-micro levels

- Conscious awareness

- Self positioning/Woman leader or leader simultaneously

- Disrupting gender binaries

- Possibilities of alternative subjectivities

Doing Gender Well \& Differently

\section{Woman As a Project}

- Holistic perspective

- Architecture of integration of women's lives

- Aspirations \& ambitions

- Agency \& understandings of gendered structures
- Commitment to organizing \& planning of self, personal \& work life

- Credibility, authenticity, leadership-efficacy, family matters, investing in your development, bravery counts

Instrumental

Personal Organizing

\section{Interlocking processes}

Figure 1. Woman as a Project: Key Issues for Women Who Want to Get On

\section{REFERENCES}

Acker, J. 1992. 'Gendering organizational theory', in A. Mills, \& P. Tancred (Eds).

Gendering organizational analysis. Newbury Park: Sage Publications, 248-260. 
Bandura, A. (1977). 'Self-efficacy: Toward a unifying theory of behavioural change', Psychological Review, 84: 191-215.

Billing, Y. D. 2011. 'Are women in management victims of the phantom of the male norm?' Gender, Work \& Organization, 3(18), 298-317.

Brown, B. (1998). Unlearning discrimination in the early years. Stoke-on-Trent: Trentham.

Bryans, P., and Mavin, S. (2003). 'Women learning to become managers: learning to fit in or to play a different game?' Management Learning, 34(1), 111-134.

Butler, J. (2004). Undoing gender. Psychology Press.

Butler, J. (1990). Gender Trouble: Feminism and the Subversion of Identity. London: Routledge.

Chesterman, C., Ross-Smith, A., \& Peters, M. (2005). 'The gendered impact on organisations of a critical mass of women in senior management'. Policy and Society, 24(4), 69-91.

Connell, R. W. (1987) Gender and power. Sydney: Allen and Unwin.

Ellemers, N., Rink, F., Derks, B., \& Ryan, M. K. (2012). 'Women in high places: When and why promoting women into top positions can harm them individually or as a group (and how to prevent this)'. Research in Organizational Behavior.

Elliott, C., \& Stead, V. (2008). 'Learning from leading women's experience: towards a sociological understanding'. Leadership, 4(2), 159-180.

Gherardi, S. (1994) 'The gender we think the gender we do in our everyday organizational lives', Human Relations, 47(6), 591-610.

Griffin, C. (1995) 'Feminism, Social Psychology and Qualitative Research' The Psychologist, 8(3), 119-21.

Jackson, C., \& Hirsh, W. (1991). 'Women managers and career progression: the British experience'. Women in Management Review, 6(2). 
Kelan, E. K. 2010. 'Gender logic and undoing gender at work', Gender, Work and Organization, 2(17), 174-194.

Knights, D. and Kerfoot, D. (2004) 'Between representations and subjectivity: Gender binaries and the politics of organizational transformation', Gender, Work \& Organization, 11(4), $430-454$.

Kumra, S. and Vinnicombe, S. 2010. 'Impressing for success: A gendered analysis of a key social capital accumulation strategy', Gender, Work \& Organization, 5(17), 521-546.

Ladge, J., Clair, J., \& Greenberg, D. 2012. 'Cross-domain identity transition during liminal periods: Constructing multiple selves as professional and mother during pregnancy'. Academy of Management Journal. 55(6), 1449-1471.

Lewis, R. and Rake, K. (2008) Breaking the Mould for Women Leaders: Could Boardroom Quotas Hold the Key? London: Fawcett Society.

Maddock, S., \& Parkin, D. (1993). 'Gender cultures: women's choices and strategies at work'. Women in Management Review, 8(2).

Mainiero, L. A., \& Sullivan, S. E. (2005). 'Kaleidoscope careers: An alternate explanation for the" opt-out" revolution'. The Academy of Management Executive, 19(1), 106-123.

Mavin, S. (2009). 'Navigating the labyrinth: senior women managing emotion', International Journal of Work, Organisation and Emotion, 3(1), 81-87.

Mavin, S. (2008). 'Queen Bees, Wannabees and Afraid to Bees: No More Best Enemies for Women in Management': British Journal of Management, 19, 575-584

Mavin, S. (2001). 'Women's career in theory and practice: time for change?' Women in Management Review. 16(4), 183-192.

Mavin, S. and Grandy, G. (2012). 'Doing gender well and differently in management', Gender in Management: An International Journal. 27(4), 218 - 231. 
Mavin, S. \& Grandy, G. (2011). 'Doing gender well and differently in dirty work', Gender, Work and Organization, available at: http: //dx.doi.org/10.1111/j.1468-0432.2011.00567.x hard copy publication (2013) 20(3), 232-251.

Messerschmidt, J. (2009) '"Doing gender": The impact and future of a salient sociological concept', Gender \& Society, 23(1), 85-88.

Morrison, A. M., White, R.P. and Van Velsor, E. (1987), Breaking the Glass Ceiling, Addison-Wesley, Reading, MA

O'Neill, O. A., and O'Reilly, C. A. (2010). Careers as tournaments: The impact of sex and gendered organizational culture preferences on MBAs' income attainment. Journal of Organizational Behavior, 31(6), 856-876.

O’Neill, D. A., Hopkins, M. M., and Bilimoria, D. (2008). 'Women's careers at the start of the 21st century: Patterns and paradoxes'. Journal of Business Ethics, 80(4), 727-743.

O'Neill, D. A., and Bilimoria, D. (2005). 'Women's career development phases: idealism, endurance, and reinvention'. Career development international, 10(3), 168-189.

Powell, G. N., and Mainiero, L. A. (1992). 'Cross-currents in the river of time: conceptualizing the complexities of women's careers'. Journal of Management, 18(2), 215237.

Ross-Smith, A., Chesterman, C. and Peters, M. (2005). 'Watch Out Here Comes Feeling! Women Executives and Emotion Work'. International Journal of Work, Organisation and Emotion 1 (1), 48-66.

Ross-Smith, A. and Kornberger, M. (2004). 'Gendered Rationality? A Genealogical Exploration of the Philosophical and Sociological Conceptions of Rationality, Masculinity and Organization'. Gender, Work and Organization 11(3), 280-305.

Sandberg, S. (2013). Lean In: Women, Work, and the Will to Lead. Virgin Digital. 
Schein, V. E. (2007). 'Women in management: reflections and projections'. Women in Management Review, 22(1), 6-18.

Sealy, R. and Vinnicombe, S. (2013). The Female FTSE Report, False Dawn of Progress for Women on Boards, Cranfield International Centre for Women Leaders, Cranfield University.

Sealy, R., Doldor, E. and Vinnicombe, S. (2009). 'Increasing diversity on public and private sector boards - Part 2. What is being done to improve diversity on boards and how effective is this?' Government Equalities Office, London.

Singh, V. and Vinnicombe, S. (2004). 'Why so few women directors in top UK boardrooms? Evidence and theoretical explanations'. Corporate Governance: An International Review, 12(4), 479-488.

Stead, V. and Elliott, C. (2012). 'Women's leadership learning: A reflexive review of representations and leadership teaching'. Management Learning.

The Sex and Power Report, Who Runs Britain. (2013). Centre for Women and Democracy on behalf of the Counting Women In coalition (CfWD, the Electoral Reform Society, the Fawcett Society, the Hansard Society and Unlock Democracy).

Tyler, M. (2005). 'Women in change management: Simone De Beauvoir and the co-optation of women's Otherness'. Journal of Organizational Change Management, 18(6), 561-577.

Vinnicombe, S. (2013). Gender, Professions and Society Forum Workshop, Newcastle University Business School, Newcastle University $28^{\text {th }}$ June.

Walby, S. (1989) 'Theorising patriarchy', Sociology, 23(2), 213-234.

West, C. and Zimmerman, D.H. 1987. ,Doing gender', Gender and Society, 2(1), 125-51. 